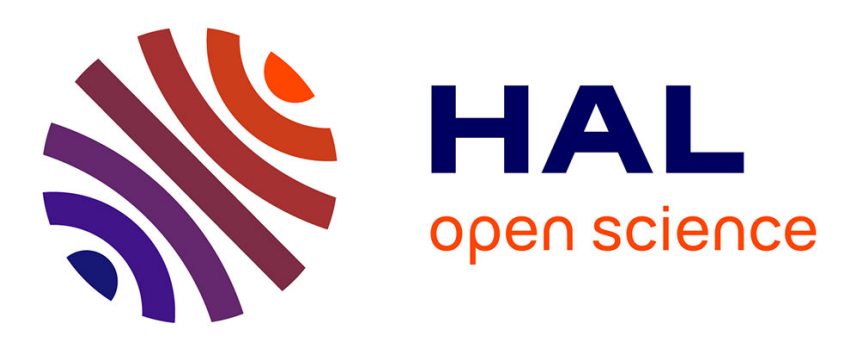

\title{
A Tipping Point in Dialect Obsolescence? Change across the Generations in Lerwick, Shetland
}

\author{
Jennifer Smith, Mercedes Durham
}

\section{To cite this version:}

Jennifer Smith, Mercedes Durham. A Tipping Point in Dialect Obsolescence? Change across the Generations in Lerwick, Shetland. Journal of Sociolinguistics, 2011, 15 (2), pp.197. 10.1111/j.14679841.2011.00479.x . hal-00634008

\section{HAL Id: hal-00634008 https://hal.science/hal-00634008}

Submitted on 20 Oct 2011

HAL is a multi-disciplinary open access archive for the deposit and dissemination of scientific research documents, whether they are published or not. The documents may come from teaching and research institutions in France or abroad, or from public or private research centers.
L'archive ouverte pluridisciplinaire HAL, est destinée au dépôt et à la diffusion de documents scientifiques de niveau recherche, publiés ou non, émanant des établissements d'enseignement et de recherche français ou étrangers, des laboratoires publics ou privés. 


\section{Journal of Sociolinguistics}

\section{A Tipping Point in Dialect Obsolescence? Change across the Generations in Lerwick, Shetland}

\begin{tabular}{|r|l|}
\hline Journal: & Journal of Sociolinguistics \\
\hline Manuscript ID: & JSLX-10-142.R1 \\
\hline Manuscript Type: & Article \\
\hline Keywords: & Lerwick, Shetland, dialect obsolescence, change \\
\hline \multicolumn{2}{|l}{} \\
\hline
\end{tabular}

\section{SCHOLARONE \\ Manuscripts}


A Tipping Point in Dialect Obsolescence? Change across the Generations in Lerwick, Shetland ${ }^{1}$

\begin{abstract}
The dialect spoken in the Shetland Islands is one of the most distinctive in the British Isles. However, there are claims that this variety is rapidly disappearing, with local forms replaced by more standard variants in the younger generations. In this paper we test these claims through a quantitative analysis of variable forms across three generations of speakers from the main town of Lerwick. We target six variables: two lexical, two morphosyntactic and two phonetic/phonological. Our results show that there is decline in use of the local forms across all six variables. Closer analysis of individual use reveals that the older age cohort form a linguistically homogeneous group. In contrast, the younger speakers form a heterogeneous group: half of the younger speakers have high rates of the local forms, while the other half use the standard variants near-categorically. We suggest that these results may pinpoint the locus of rapid obsolescence in this traditionally relic dialect area.
\end{abstract}

Key words: Lerwick, Shetland dialect obsolescence change Short running title: Dialect change across the generations in Lerwick, Shetland. Word count: 8524 


\begin{abstract}
French
Le dialecte parlé dans les Shetlands est une des plus distinctives des Iles Britanniques. Cependant, certains prétendent que cette variété est en voie de disparition et que les formes locales sont en train d'être remplacées par des variantes plus standards dans le parler des plus jeunes générations. Dans cet article, nous analysons cette affirmation au travers d'une analyse quantitative de formes variables sur trois générations de locuteurs habitant la ville principale des Shetlands, Lerwick. Nous examinons six variables: deux lexicales, deux morphosyntaxiques et deux phonétiques/phonologiques. Nos résultats montrent que les formes locales sont en déclin pour les six variables considérés. Une analyse plus approfondie de l'usage individuel du langage montre que les locuteurs plus âgés forment un groupe linguistiquement homogène, tandis que les locuteurs plus jeunes forment un groupe hétérogène. La moitié du groupe des plus jeunes utilise un pourcentage élevé de formes locales, tandis que l'autre moitié utilise les variantes standards presque catégoriquement. Nous suggérons que ces résultats peuvent nous indiquer la source d'obsolescence rapide dans ce site où le dialecte a traditionnellement été maintenu.
\end{abstract}




\section{INTRODUCTION}

Research on varieties of English in the British Isles over recent years indicates widespread loss of traditional dialect forms, resulting in dialect 'attrition' across many speech communities. Britain, for example, (2005:35), observes that 'In most cases, and in most places, dialect variation seems radically less marked, less divergent and less locally oriented than that spoken one hundred years ago'. 'Dialect levelling' is seen to be at the core of this process (e.g. Foulkes and Docherty 1999, Kerswill 2003) where young speakers in particular are noted to avoid 'variants which they perceive to be particularly indicative of their local roots' (Foulkes and Docherty 1999:13). Moreover, evidence suggests that such attrition 'has affected every structural level of the language' (Britain 2009:123) resulting in 'dedialectalisation' (Trudgill 2002:33). and perhaps even dialect death.

The prevalence of loss of traditional forms is highlighted by claims regarding one of the most remote communities in the British Isles, the Shetland Islands in Northern Scotland. Because of Shetland's peripheral geography, coupled with historical socio-cultural isolation, it is said to represent one of 'the best examples of a relic speech form' (Johnston 1997:447), where 'the localised dialect is used by nearly everyone to insiders' (ibid:449). However, it is claimed that socio-economic, cultural and demographic changes arising from a highly developed infrastructure in recent decades have led to 'an unprecedented levelling of the local varieties in recent years' (van Leyden 2004:18), particularly in the main town of Lerwick. Tait (2001:11) goes even further, stating that 'the change which is taking place is not a gradual blending of one form of speech into another: it is the abrupt replacement of one language phonology, morphology and syntax as well as vocabulary - by another.' 
These statements suggest that this geographically peripheral and historically isolated community may be undergoing rapid dialect erosion and perhaps even dialect death. However, the empirical evidence to support such claims is sparse: despite some excellent historical and contemporary research on the linguistic situation in the Shetland Isles, to date there have been no studies which provide a time-depth analysis of change in recent generations. In this paper we address this gap by conducting a quantitative, sociolinguistic analysis of a number of linguistic variables across three generations of speakers in Shetland. We expect to find change in the dialect: Shetland would be quite unique if there were none. However, our purpose in this paper is to uncover 1) how rapid this change is and 2) how the change proceeds. Do all individuals participate in the change? Do all linguistic forms? If traditional forms are shown to be obsolescing, is the change 'incongruent and idiosyncratic' (Cook 1989: 235), or characterized by more systematic retreat across the linguistic and social landscape (e.g. Schilling-Estes \& Wolfram 1999, King 1989)? Through this analysis, we hope to increase 'our understanding of the linguistic process and the sociolinguistic context of language obsolescence' (Wolfram 2002:764-5) in Shetland which may in turn inform more generally on the issues of dialect levelling, attrition and death in varieties worldwide.

We first situate the research in the wider context of the Shetland Isles past and present.

SHETLAND: LINGUISTIC AND SOCIAL HISTORY 
The Shetland Isles is situated in the North Sea, between Norway to the east and Scotland to the south (Figure 1). Its social and linguistic history, both distant and more recent, makes it an ideal site for investigation of change in dialect norms. [FIGURE 1 ABOUT HERE]

Shetland was invaded by the Vikings in the $9^{\text {th }}$ century, and with these invaders came the language of Norn. This language largely eradicated the indigenous languages of the time and was spoken in Shetland for over 800 years (e.g. Barnes 1998:2) until it started to be replaced by Scots from the $16^{\text {th }}$ century. Debate remains about exactly how, when and why Scots replaced Norn (e.g. Barnes 1998, Rendboe 1984) but a key point was the annexation of Shetland by the Scottish crown at the end of the $15^{\text {th }}$ century (ibid). A situation of bilingualism is said to have existed in the following period (e.g. Smith 1996) and by the beginning of the $18^{\text {th }}$ century Norn as a first language was rare and had largely died out by the end of that century (e.g. Barnes 1998:27).

The present day Shetland dialect is described as a variety of Scots, with elements from both Older Scots and the Norn substratum still in evidence (e.g. Tait 2001:10, Melchers 2004a:285). This results in a number of traditional lexical, morphosyntactic and phonological forms, some of which are unique to the Shetland Isles, and some used more widely throughout Scotland, as shown in the following extract from Lisa, an 18 year old speaker:

(Extract 1) Yeah, this was Capetown. And we started driving oot and er I mind pullin' up ootside this- we got into this, like, road, pullin' up ootside this tiny peerie like hoose and there was all this like peerie kind of like corrugated iron shacks aroon' it. And all this- just all this folk just wanderin' aboot and that, just dirt and mess everywhere and I just mind 
thinking 'Oh please God, let yon be his, let yon be his house'. And then he said 'This Lisa- this is where you're staying' and I was just like 'Ooh, what have I done' sort of thing. And so I got oot of the car and then, the wife like kind of introduced me to this folk and I gied inside this tiny, tiny, peerie hoose, it was just two rooms. Probably the rooms put together was peerier as this room. And er gied in, they started speaking in yon Xhosa, that's what the- like the kind of dialect they spoke and they started speaking that the whole time.

Gloss (sections glossed are in italics): Yeah, this was Capetown. And we started driving out and er I remember pulling up outside this- we got into this, like, road, pulling up outside this tiny small like house and there was all this like small kind of like corrugated iron shacks around it. And all thisjust all these people just wandering about and that, just dirt and mess everywhere and I just remember thinking 'Oh please God, let that be his, let that be his house'. And then he said 'This Lisa- this is where you're staying' and I was just like 'Ooh, what have I done' sort of thing. And so I got out of the car and then, the woman like kind of introduced me to these people and I went inside this tiny, tiny, small house, it was just two rooms. Probably the rooms put together were smaller than this room. And er went in, they started speaking in Xhosa, that's what the- like the kind of dialect they spoke and they started speaking that the whole time.

It is said that highly localised features (e.g peerie for small, as for comparative than), in tandem with more Scotland-wide features (e.g. yon for that, a monophthongal variant in words such as out and around) are widely used by speakers in Shetland. For example, van Leyden (2004:17) points out that 'There is no Scottish 
Standard English speaking middle class and virtually all native speakers, from manual workers to university graduates, employ the local dialect in their everyday speech' (see also Johnston 1997:449). Using a standardised form of Scottish English is said to be much maligned (Melchers 1985:98), and even has a particular word to describe it: knapping. However, this situation may be changing: in more recent years, Shetland has seen an influx of outsiders due to the oil boom, and in particular the building of the north sea oil rig terminal at Sullum Voe between 1973 and 1982, with up to 6,000 people employed on the site. Opinions differ as to the effects of this outsider influence. Johnston (1997:449) states that it was felt to be something temporary, which has left the region more prosperous 'but essentially locally-oriented'. Population statistics show that only a small percentage of the workers settled permanently after the terminal was completed in the 1980s. On the other hand, the 2001 census showed that around $15 \%$ of people living in Shetland have come from outside of Scotland and this figure may be growing (Scotland Census 2001). Whereas in the past these in-migrants 'generally acquired the local dialect' (van Leyden 2004:18, see also Scobbie 2005), in more recent times it is claimed that rather than a process of assimilation, a type of standardised Scottish English is becoming the norm. Melchers (2004a:37) states that it is 'difficult to find truly monolingual speakers of the traditional dialect today', even with families who have lived there for generations. However, instead of complete dialect loss, she suggests that a situation of bidialectalism prevails, where speakers 'have access to a choice of two discrete, definable forms of speech: 'English' vs. 'Shetland' (ibid:37).

The view from the ground, as it were, indicates that the speakers of Shetland themselves think that the dialect is under threat as evidenced from these extracts from the present study: 
Extract 2: Bob, age 72

(Bob) I was speakin' earlier on aboot, du kens, age groups. I don't thinkthe young ains at school now is speaking the Shetland dialect or the Lerwick dialect. Maybe- maybe there's still a touch o' dialect throughoot the country but I don't think youngsters in Lerwick now is speakin' the dialect or whatever you think would be the dialect and er- I mean, I- I can see it to a certain extent with wir own family. Du kens, it- it's no, certainly no separate now. (Interviewer) Du'll ken with the younger ains yeah. No, no. And I noticed like I don't know if du's noticed with your ains, your- boys and your daughter-in-law when they're gettin' onto the bairns, will they go into English? (Bob) They go into English. That's right. Yeah, that's right. Ththey go into- whereas we- we were, when we were bairns we just spoke away-. (Interviewer) They'll 'talk'. They'll give them a telling off in English!

Gloss: (Bob) I was speaking earlier on about, you know, age groups. I don't think- the young ones at school now are speaking the Shetland dialect or the Lerwick dialect. Maybe- maybe there's still a touch of dialect throughout the country but I don't think youngsters in Lerwick now are speaking the dialect or whatever you think would be the dialect and er- I mean, I- I can see it to a certain extent with our own family. You know, it- it's no, certainly not separate now. (Interviewer) You'll know with the younger ones yeah. No, no. And I noticed like I don't know if you've noticed with your ones, your- boys and your daughter-in-law when they're getting onto the children, will they go into English? (Bob) They go into English. That's right. Yeah, that's right. Th- they go into- whereas we- we were, when we were children 
we just spoke away-. (Interviewer) They'll 'talk'. They'll give them a telling off in English!

Extract 3: Mary, age 54

(Mary) I suppose at a time as well when, uh, I wouldna say it was just as popular to speak dialect. Certainly when we were at school, you werena supposed to say anything in dialect at the school or you got- you certainly got flitten on badly. But, uh, it's different now, I think, although the bairns might be encouraged, sadly I would think there's probably a lot less dialect spoken. (Interviewer) I think that's right. Du goes by the playground, du can hear that. (Mary) But then there's- there are probably a lot more different influences now. They've got, uh, well they've got the television for a kick off (inc) the groundin' for the bairns, they've- they're been exposed to such a huge range of different ways of speakin', which we werena.

Gloss: (Mary) I suppose at a time as well when, uh, I wouldn't say it was just as popular to speak dialect. Certainly when we were at school, you weren't supposed to say anything in dialect at (the) school or you got- you certainly got picked on badly. But, uh, it's different now, I think, although the children might be encouraged, sadly I would think there's probably a lot less dialect spoken. (Interviewer) I think that's right. You go by the playground, you can hear that. (Mary) But then there's- there are probably a lot more different influences now. They've got, uh, well they've got the television for a kick off (inc) the grounding for the children, they've- they're been exposed to such a huge range of different ways of speakin', which we weren't. 


\section{Extract 4: Valerie, age 17}

(Interviewer) Ok, and can you recognise where people are fae, fae their accent? (Valerie) Yeah, kind of. You probably- well the islands are really obvious. Sooth end that sounds really the same. But like places like Yell and that you notice. But some folk dinna even- there's quite a lot of folk dinna hae a accent. One of my- a couple of my pals dinna speak the Shetland dialect at a'.

Gloss: (Interviewer) Ok, and can you recognise where people are from, from their accent? (Valerie) Yeah, kind of. You probably- well the islands are really obvious. South end that sounds really the same. But like places like Yell and that you notice. But some folk don't even- there's quite a lot of folk don't have an accent. One of my- a couple of my pals don't speak the Shetland dialect at all.

Thus on the one hand, the Shetland dialect is said to remain quite unique, but on the other hand, this uniqueness may be disappearing to be replaced by more supralocal norms. How can these differing claims on the current state of the dialect be corroborated? There are a number of works from both a diachronic and synchronic perspective, encompassing lexical, grammatical and particularly phonological/phonetic perspectives on the Shetland dialect which provide invaluable descriptions of the Shetland dialect (e.g. Bugge 2007, Catford 1957, Jakobsen 1921/1928, Jonas 1996, Melchers 1985, 1991, 1996, Murison 1954, Robertson and Graham 1952/1991, Scobbie 2005, Smith 1996, Sundkvist 2004, 2007, van Leyden 2004). However, as already mentioned, there are no studies which provide a 
sociolinguistic time-depth analysis of this variety which would allow us to assess the extent of change in the dialect over the past 100 years. It is to this question that we now turn.

\section{DATA}

For this study, we chose to focus on the main town of Lerwick (Figure 2), the commercial and industrial centre of Shetland, as it is often pinpointed as the locus of most rapid linguistic change (e.g. Tait 2001:8, van Leyden 2004).

\section{[FIGURE 2 ABOUT HERE]}

It has a population of approximately 7,500 (although half of the islands' 22,000 residents live within 10 miles of the town) and is the UK's northernmost town, being closer to Bergen in Norway than to the city of Aberdeen. Since the late 1970s, inmigration from the surrounding outer isles to Lerwick has been common, in addition to a number of incomers from mainland Scotland and England brought by the reorganisation of the local government structures and the oil industry. Unemployment is well below the national average. As with most other areas, the biggest employer is the service industry, although fishing is still an integral part of the Lerwick way of life. The 2001 census shows that approximately $8 \%$ of the population are in Class 1 of the Registrar General's Social Class scale i.e. professionals: the remaining population is spread fairly evenly between Classes 2-5, including skilled non-manual occupations and unskilled labour. It has one high school with approximately 900 pupils, and five primary schools.

There is 'considerable regional diversity' (van Leyden 2004:17, see also Johnston 1997:448) in the dialects spoken on the Shetland Isles, brought about by 
little contact in previous years between the islands dotted around the archipelago.

Whalsay, in particular is said to differ substantially from all other Shetland varieties (van Leyden 2004:17). For this reason, we do not claim that Lerwick is representative of the Shetland Isles more generally, but merely represents one particular variety (or indeed varieties) of many on these islands ${ }^{2}$.

\section{CORPUS}

Judgement sampling (e.g. Feagin 1979), where a number of predetermined categories are sought, was used in the initial data collection stages of the project. The sample contains 30 adults, equally divided by age and sex. Three age ranges were targeted (17-21, 45-55, 70+) in order to assess change in 'apparent' time (e.g. Bailey 2002). These groups represent three generations of speakers but also represent different 'life stages' (e.g. Eckert 1998:151): the 17-21 year olds are all post-school 'young adult', relatively new to the work context; the 45-55 year olds are well established in the linguistic marketplace, but with family at the heart of their concerns; the 70+ year olds have all been retired for some time. Males and females are included to test for any possible gender effects on use of the variable forms (e.g. Labov 1994). To control the sample as much as possible, participant selection was guided by the following criteria: 1) informant born and raised in Lerwick 2) parents and spouses born and raised in Shetland, 3) informants in Class 2-5 according to the Registrar General's Social Class Index. It should be noted that some of the speakers in all age groups had spent time off the island. However this was not viewed as a barrier to inclusion in the study, as this is a reflection of the Lerwick demographic, where people do often spend 
at least some time away from the community. For this study, we did not include any speakers who had spent more than one continuous year off the island.

Despite in-migration in the past couple of decades, Lerwick continues to be a close-knit community (e.g. Melchers 1985), which has implications for gaining access to potential informants (e.g. Labov 1972). To mitigate these problems, interviews were conducted by three locals who are well-embedded within the community structures. Participants were contacted directly by the interviewers and in some cases, the 'friend of a friend' approach (Milroy 1980) was used. The data were collected using standard sociolinguistic techniques (Labov 1984) and lasted from between 1-2 hours. To further mitigate the Observer's Paradox (Labov 1972) the interviews took place in the informants' homes. A portable Marantz PMD671 Digital Audio Recorder was used with lapel microphones in order that the equipment be as unintrusive as possible.

The data are fully digitised and transcribed using Praat, software which allows speech to text synchronization and spectrographic analysis. The transcriptions were spot-checked by a native Shetlander in order to ensure accuracy of transcription.

\section{THE LINGUISTIC VARIABLES}

Recall Britain's (2009:123) suggestion that dialect attrition affects 'every structural level of the language', and more specifically Tait's (2001) claim that all aspects of the traditional Shetland dialect - phonetic, morphosyntactic and lexical - are being lost. To test these claims, we target six variables, two from each area of the grammar. The variables are also differentiated in terms of national versus more local use in this Scottish context. Three of the variables are attested throughout Scotland while the 
remaining three are more local to Shetland (e.g. Millar 2007). We designate these Scotland-wide and Shetland-specific. In this division we do not claim that Shetlandspecific features are unique to that area. Indeed, one of the variables to be analysed, th-stopping, is widespread in dialects worldwide. This categorisation simply rests on whether they are used throughout Scotland, or are more locally affiliated to Shetland.

Britain (2009:123) describes attrition and death as 'the erosion of traditionally locally embedded dialect (including accent) feature or features in favour of one originating outside the community or from another group within the same community'. In each of these variables, there is variation between a local/traditional variant and a Standard (Scottish) English variant (i.e. from outside the community). Our analysis focuses on use of variable forms across the three generations of speakers. However, as has been shown in previous analyses (e.g Guy 1980, Petyt 1980:188-90), these types of groupings may eliminate individual variation, particularly in cases of rapid obsolescence where 'speakers might show highly specific patterns of variable usage' or 'personal-pattern variation' (Dorian 1994:634, see also Johnstone 2000) rather than community shared norms documented more generally (e.g. Labov 1972). Thus, we further analyse the variables across individual speakers. We then investigate a number of linguistic constraints which may shed light on how the change proceeds. Specifically we test a number of claims with respect to language obsolescence and the linguistic system: whether the pathway of attrition is characterised by overgeneralization or hypercorrection of language features (e.g. Cook, 1989: 235, Dorian 1994, Wolfram \& Schilling-Estes, 1995), or more in line with 'orderly differentiation' (Weinreich, Labov \& Herzog 1968), where even at the endpoint of change, there is retention of constraints (Jones \& Tagliamonte 2004). In the latter case, 'it is probable 
that language death does not differ in kind from other type of linguistic change, but in the speed with which structural changes occur and in the number of phenomena covered by the process' (Tsitsipis 1989: 117).

We now turn to the variables under analysis.

Lexical Variables

$\underline{\text { Shetland specific: peerie }}$

The first lexical variable is peerie and its variants small, tiny and little as in (1):

1. a. We first bade in Union Street, when I was peerie. (Doreen, old)

b. It seemed like quite far when we were little. (Michelle, young)

c. When I was small, we were at my granny's a lot. (Rory, young)

Although its etymology is uncertain (the OED describes it as "probably $<$ the unattested Norn reflex of the early Scandinavian word represented by Swedish pirig...'), it is first attested in writing at the beginning of the $19^{\text {th }}$ century. van Leyden (2004:27) suggests that in present day Shetland it is 'employed as a kind of positive shibboleth to emphasise ... Shetland loyalty' ${ }^{3}$.

Scotland-wide: ken

Use of ken for know as in (2) is another stereotype, although this time a national, rather than specifically Shetland, one.

2. a. You'd sit in and you'd ken a' the tunes. (Lisa, young)

b. They kent over well what I was done (Jim, middle) 
c. Du know, sometimes you go into a shop here, du kens...(Bob, old)

This form has been around since the 1300s (OED s.v. ken) but is still commonly used throughout Scotland (e.g. Miller 1993). We include both discourse marker (2c) and lexical verb (2a, 2b) use. Figure 3 shows use of these variants across the 3 generations. The total number of contexts of use are also indicated on the graph to provide clear information on how robust (or sparse) the variable is across the 3 generations and the individuals (e.g. Guy 1980).

[FIGURE 3 ABOUT HERE]

Figure 3 shows that for the three generations, peerie and ken are the majority variants, although the rates of these forms decrease across the age groups. There is a statistically significant difference among the three groups for both peerie $\left(\chi^{2}=22.89\right.$, $\mathrm{p}<0.001)$ and ken $\left(\chi^{2}=167.96, \mathrm{p}<0.001\right)$. The difference between the old and middle groups is also statistically significant for both lexical items. Closer investigation revealed that these local forms were also the majority variants across all individuals in the middle-aged and older speakers. The younger speakers, in contrast, are different, as demonstrated in Figure 4.

\section{[FIGURE 4 ABOUT HERE]}

Figure 4 shows that for peerie, five of the younger speakers (Joanne, Valerie, Jake, Stewart and Lisa) have similar rates of use to the older generations with peerie the majority form. Mark and Rory use the form less and the three remaining speakers - Sean, Michelle and Erika - don't use the specifically Shetland form at all. In other words, the middle-aged and older speakers form a fairly homogeneous group, but the younger speakers are characterised by a high degree of inter-speaker variability and a local/non-local split in rates of use. The complete absence of use with three of the 
younger speakers makes it impossible to test for statistical significance, although the percentages clearly show the polarised use.

Ken provides an even starker contrast amongst the younger speakers: five of the speakers use it near categorically and the other five use the standard equivalent know near categorically.

We have examined a number of other lexical variables (e.g. big vs build, aye vs. yes). These pattern in the same way, with the older speakers demonstrating homogeneous patterns of use and the younger speakers demonstrating heterogeneous use.

However, these patterns of use may be unique to lexical variables, as these are said to be one of the most salient features of speech (e.g. Trudgill 1986: 24). We now turn to the morphosyntactic variables to see if the same patterns apply.

Morphosyntactic variables

\section{$\underline{\text { Shetland specific: be perfect }}$}

In the Shetland dialect, be can appear in perfect contexts where Standard English appears with have (e.g. Millar 2007:75, Melchers 2004a: 39, Pavlenko 1997, Robertson and Graham 1991:11), as demonstrated in (3):

3. a. I'm no been in Imelda's in a start. (Joanne, young)

b. By the time you've come home... (Joanne, young)

c. Funnily enough, they were been coopers as well. (Brian, old)

d. I think he'd been in intelligence. (Brian, old)

$B e$ perfect is described as 'perhaps the most striking structural feature' of the Shetland dialect (Millar 2007:75) and its use is more productive when compared to 
either the historical record (e.g. Kytö 1997) or present day varieties of English elsewhere (e.g. Tagliamonte 2000, Wolfram 1996). It can appear with transitive and intransitive verbs, present and past tense, and with a variety of subject types. This has led to considerable debate surrounding its provenance - a reflex of a Norn substratum or remnant from the history of English (e.g. Melchers 1996:291, 2004a, Pavlenko 1997). However this question is beyond the scope of this research: crucial for our purpose is how this Shetland-specific variable patterns in apparent time ${ }^{4}$.

\section{$\underline{\text { Scotland-wide: singular distal demonstrative yon }}$}

The second morphosyntactic variable we analyse is the use of yon in variation with that in singular distal demonstratives contexts, as in (4):

4. a. I was just like 'What's yon?' (Joanne, young)

b. Still actually hae yon BMW that I met the girlfriend with. (Stewart, young)

c. Buy another ain and get bored of that ain and sell it. (Stewart, young)

d. Couldna mind a thing that she'd done that morning. (Helen, middle)

Despite its appearance in the Middle English period, yon is first attested in Scots in the $19^{\text {th }}$ century (e.g. King 1997:168). It was said to indicate 'a person or thing at some distance in time or space, generally more remote than that.' (SND 1976:286). Melchers (1997) suggests that in Shetland, it is part of a three-dimensional system, with yon used to signal emotional distance, demonstrated in its use with nonShetland phenomena. In contrast, Robertson \& Graham (1991:4-5) suggest that yon is 'used of things near in time and place, while dat [that] is used of things past or more remote'. Due to the debate over its semantic and pragmatic circumscription, in line 
with Sankoff \& Thibault (1981), we include all singular distal demonstrative contexts. Figure 5 shows the use of these two variables across the three generations.

[INSERT FIGURE 5 HERE]

Note first the use of be for have. The middle aged and older speakers have fairly similar percentages of use $-62 \%$ and $54 \%$ respectively. The younger speakers have significantly lower rates: $25 \%$ overall. There is a statistically significant difference between the old/middle speakers and the young speakers: $\chi^{2}=83.57, \mathrm{p}<$ 0.001 .

Yon patterns differently. First, across all age groups, there are very low rates of use of the dialect form. However, yon has always been a marginal form in the history of English (e.g. Dons 2004:146), thus it is not surprising to see its infrequent use in present day Shetland. It might be more surprising that marginal form such as yon appears to be 'holding its own' across the generations. In fact, the younger speakers have higher rates of use for it than the older generations. This difference is statistically significant $\left(\chi^{2}=9.02, \mathrm{p}<0.05\right)$.

Again, we investigated further the use of these forms by individual speakers. For be perfect, in the middle aged and older age groups, all speakers show variable use although the range is quite wide: $23-85 \%$ (This may be due to small Ns across some individuals). For yon, 19 of the 20 older speakers use it in variation with that, ranging from $4-10 \%$.

Figure 6 shows how these variables pattern in the individual younger speakers. [INSERT FIGURE 6 HERE]

Although there is more of a continuum of use with be perfect when compared to the lexical variables, the same basic pattern emerges: 5 of the speakers use the local form, and 5 hardly use it at all. Note that for the variable speakers, there is a wide 
range of rates of use, ranging from the high 80 s to the low 20s. Again these divergent rates may be the product of low numbers of contexts of use, but whatever the reason, they are in line with the range found in the older speakers. We further investigated a range of internal constraints on use attested in the literature, including subject type, transitivity and tense (e.g. Dannenberg 2003, Tagliamonte 1997) across the older and middle-aged speakers and the younger variable speakers. Figure 7 shows one of these: use of the form by tense across the three generations.

\section{[INSERT FIGURE 7 ABOUT HERE]}

Figure 7 demonstrates maintenance of constraints, where be is more likely to be used with the present tense than past. Across each age group, the difference is statistically significant. For the old speakers: $\chi^{2}=21.15, \mathrm{p}<0.001$; for the middle aged speakers: $\chi^{2}=32.78, p<0.001$; for the young speakers: $\chi^{2}=35.05, p<0.001$. A number of other constraints showed the same patterns of use (see Smith \& Durham in progress).

The results for individual younger speakers use of yon differ from the older and middle-aged groups. Only 4 of the speakers use the form to any extent - Valerie, Joanne, Lisa and Stewart. The 6 remaining speakers show (near) categorical use of that (Rory and Mark have one token each of yon). Second, Valerie and Joanne have extremely high rates of yon: $36 \%$. This is far in excess of the frequencies of use found for the older generations.

How do these younger variable speakers pattern in terms of constraints on use compared to the older speakers? We further divided the data into pronominal (4a) versus determiner use $(4 \mathrm{~b})$. Figure 8 shows the results.

[INSERT FIG 8 ABOUT HERE] 
Figure 8 shows that for the older and middle-aged speakers there are higher rates of yon in determiner contexts when compared to pronominals. The variable younger speakers, including Joanne and Valerie, the extremely prolific yon users, show the same constraints on use. We also note however, the low Ns for Valerie. Chi square tests comparing determiners and pronouns for each of the age groups (the low Ns for the young speakers make it impossible to test them individually) show that the differences are highly statistically significant in each group (old, $\chi^{2}=24.32, \mathrm{p}<$ 0.001, mid: $\chi^{2}=88.42, p<0.001$, young $\left.\chi^{2}=60.55, p<0.001\right)$.

Phonetic/phonological variables

\section{Shetland-specific: th- stopping}

The next feature we analyse is the use of so called th- stopping (Wells 1982: 565-6) where $<$ th $>$ is realized as a stop rather than a fricative, as in (5).

5. But I mind one particular day /ð/at I was bouncing in /d/e crib, and it broke. (Agnes, old)

Although there is debate regarding its etymology (see e.g. Melchers 2004b:42, Barnes 1998), it is claimed that the use of $[\mathrm{d}]$ and $[\mathrm{t}]$ for $/ ð /$ and $/ \theta /$ in word initial and medial positions 'is a general feature of Shetland speech' (van Leyden 2004:20), especially amongst 'traditional dialect speakers' (Millar 2007:62). Melchers (2004b:42) goes as far as to say that it is '....categorical in Shetland accents, unless adapted to outsiders'. Here we concentrate on contexts of voiced dental fricatives only ${ }^{5}$. Despite the fairly straightforward claims that /ð/ is substituted by [d], what we found in our data was a cline of variants, some more stop-like and others more fricative-like. We initially 
divided the data into two main categories: stops and fricatives, with further divisions detailed below.

\section{Scotland-wide: $l$ vocalization}

Johnson and Britain (2007:295) amongst others, note that l-vocalisation, vocalisation of the phonetically 'dark' /l/ in syllable rhymes, is widespread in Southern British English. However, in Scots, a different type of 1-vocalisation exists: syllable-final /al, ol, ul/ can be vocalized, as in (6) (e.g. Macafee 1983:38), resulting in orthographically realized forms such as $a^{\prime}$ for $a l l, b a^{\prime}$ for ball, and $c a^{\prime}$ for call.

6. a. So we /a/ gied down there. (John, old) b. What do you c/al/ it? (Valerie, young)

This type of 1-vocalisation is no longer productive in Scots (e.g. Stuart-Smith, Timmins and Tweedie, 2007:232) with the result that in present day varieties it is restricted to a small lexical set. We include only those lexical items which were shown to vary.

Figure 9 shows how these two variables distribute across the generations. [INSERT FIGURE 9 HERE]

For l-vocalisation, both older and middle-aged speakers have rates over 50\% and there is actually a rise in use of the local variant in the middle-aged speakers. This decreases significantly in the younger speakers (Old compared to mid: $\chi^{2}=8.75, p<$ 0.01 , young compared to old and mid: $\left.\chi^{2}=32.11, \mathrm{p}<0.001\right)$. The younger speakers on the other hand, show a considerable decrease in use. Th- stopping shows a more gradual decrease in use although, again, the difference between the generations is statistically significant (Old compared to mid: $\chi^{2}=9.89, \mathrm{p}<0.01$, young compared to 
old and mid: $\left.\chi^{2}=213.45, \mathrm{p}<0.001\right)$. What is probably more striking is the relative paucity of stop variants across even the middle aged and older speakers, despite the claims that this variant predominates in Shetland speech. In fact, when individual use amongst the middle aged and older speakers was investigated, 13 of the 20 speakers used the dental fricative, i.e. the standard form, as the majority variant.

Figure 10 shows how the younger individuals pattern across these variables.

\section{[INSERT FIGURE 10 ABOUT HERE]}

1-vocalisation replicates a now familiar pattern: half of the speakers have high rates of the local form, and the others have virtually none. The lexical set in which 1vocalisation was used in the older speakers was replicated in the younger variable speakers. In other words, no change in lexical constraints on use.

Th- stopping looks somewhat different when the younger speakers are considered individually. Although there are three speakers who are near categorical in their use of the standard variant, there is more gradient stratification amongst this younger cohort. In other words, a monotonic, step-wise pattern. Moreover, there is no evidence of the heightened rates of use with some speakers as exemplified in e.g. the use of yon. Another intriguing pattern emerges in a further breakdown of the data: in the stop category, two variants emerge: a dental stop and an alveolar stop. We now further divide the data to reflect this split in the stop-like variants. Figure 11 shows the results.

\section{[INSERT FIGURE 11 ABOUT HERE]}

Note the use of the dental stop and the alveolar stop in Figure 11. For the middle-aged and older speakers the hierarchy of use is dental fricative $>$ dental stop>alveolar stop but for the younger speakers the hierarchy of use is reversed: dental fricative $>$ alveolar stop $>$ dental stop. We return to this point in the discussion. 


\section{DISCUSSION}

Despite evidence for dialect loss in the British Isles, Britain (2009:123-124) points out that there have been very few studies of 'the attrition process in action, for example through Labovian apparent time studies of individual speech communities'. We believe that this apparent time study provides a good demonstration of that process, and allows us to assess more fully the claims regarding language attrition and death in one community in Shetland. Specifically, is there an 'abrupt replacement of one language - phonology, morphology and syntax as well as vocabulary - by another' (Tait 2001)?

For all of the variables studied, whether lexical, morphosyntactic or phonetic/phonological, the results showed a decline in use of the local, traditional forms in favour of more standardised variants across the three generations of speakers. However, closer analysis of individual use within each age cohort demonstrated a generational divide: homogeneity in variable use in the middle-aged and older speakers, but heterogeneity amongst the younger speakers. In other words, sharp stratification in the younger cohort across most of the variables studied, with some of the speakers showing high rates of the local forms (in some cases even higher than the older generations) and the others having extremely high rates of the newer, standard variants. Thus, there is abrupt change and extreme dialect levelling with some speakers, as Tait (2001) suggests, but not with others. How can these results be explained? 
We suggest that these results may be indicative of rapid dialect attrition. Language change 'is predominantly gradual, and very frequently regular' (McMahon 1994:6), with 'small - and socially manageable increments - along the age continuum' (Chambers 2002:366). However, these results look much more like 'catastrophic' change, with the replacement, at least with some speakers, of one variety by another in the space of one generation. In these data, there are no 'semi-speakers' (Dorian 1977) characteristic of gradual language shift. Such catastrophic changes normally occur in situations of extreme social disruption, e.g. invasions or massive immigrations, resulting in radical rearrangement of the internal structure of the community (e.g. Labov, 2001:262, Campbell \& Muntzell 1989). As detailed in the section on Shetland's social history, there have been changes in the demographic of Shetland over the past few decades with the advent of the oil industry, but no major upheavals of the type Labov, amongst others, describes.

Instead, we propose that social changes more generally may have precipitated these linguistic changes in Lerwick. Wolfram and Schilling-Estes (2006:118) state that 'As some of the more remote areas of the nation are open to intercommunication with the outside world, their distinctive language varieties, fostered in isolation and spoken by relatively small numbers of speakers, may be overwhelmed by encroaching dialects'. While in the past Lerwick may have been a closed community, it is now undoubtedly more open to external forces, in this case a more standard variety of the language. This is echoed in Extract 3 above from Mary (amongst many other speakers), who suggests that 'there's probably a lot more different influences now' with the children 'exposed to a huge range of different ways of speaking' which the older generations were not. This exposure may have produced a 'tip' (Dorian 1981:51, 1986) where 'a language which has been demographically highly stable for 
several centuries may experience a sudden "tip" after which the demographic tide flows strongly in favour of some other language'. We suggest that this research may have pinpointed that change, with the tide flowing in favour of a more standardised variety in the younger speakers.

However, if the Lerwick dialect has reached this 'tip' what can explain the polarised use of forms amongst the younger speakers? Gender might be an obvious starting point in explaining the split in use, with the expectation that males will have higher rates of vernacular forms when compared to females (e.g Labov 1972). However, across the variables, three of the five females have higher rates of the local forms and only two of the five males. Thus, the variables do not pattern across established gender norms. Can the individual speaker profiles of the younger speakers provide any clues to the heterogeneous language use evidenced in this generation?

In general, the speakers share the same socio-cultural backgrounds (same agegroup, all parents from Shetland, live in Lerwick, attended same High School). The speakers were differentiated however, in terms of one potentially important indicator: time off the island. Jake, Stewart, Erica, Sean, Rory had spent no time off the island other than for short trips. Lisa and Mark have had one year off the island to study (but with regular trips back home during this time). Michelle, Joanne and Valerie all intended to leave in the next few months for study. It might be hypothesized that this may have an impact on their language use through, for example, face to face accommodation with speakers of other varieties of English while living on the mainland (e.g. Trudgill 1986). However, Lisa is one of the more dialect speakers, and Mark one of the most standard. Jake and Stewart use local forms, but the remaining three are very standard in their speech. Joanne and Valerie use very high rates of the 
local forms, while Michelle uses hardly any. Thus there is no simple correlation between time off the island and language use.

Another influencing factor on speech patterns might be affinity with Lerwick and Shetland more generally. Although the study did not set out to elicit specific information on attitudes (e.g. Llamas 2000), the interviews contain many incidental comments which reveal speakers' opinions. Crucially, all of the younger generation spoke favourably of Shetland, expressing either a desire to stay on the island, or to return at some point. A typical example is from Rory:

(Extract 5) And then when I finished school I thought I would take a year out and try and make up some money for actually goin' away but takin’ the year out I gained full employment, and I was quite happy. Got my girlfriend up here and most of my family, a lot of my mates so I- I find it quite difficult to go down South. I think I would get homesick, so decided to stay where I was for the moment.

This affinity with Shetland is at odds with his speech patterns: Rory is one of the most standard speakers in the sample.

Another hypothesis might be different social networks within this age group (e.g. Milroy 1980). Strikingly, the tightest network, Joanne, Valerie and Michelle, who declared themselves 'best friends,' exhibited stark differences in dialect use. Valerie and Joanne had the highest use of traditional forms across all variables, while Michelle had the lowest. Moreover, while 'dialect death can be gradual and (to the speakers at least) virtually imperceptible' (Hinskens, Auer \& Kerswill 2005:11), the younger speakers are very aware of these differences, as highlighted in the extract from Joanne in Extract 6:

(Extract 6) And with my pals, they were sayin' about me and Valerie, 
she 's just- me and her's just likely the broadest ains of the lot of wis. Cos my other pals, they bide in Lerwick and their mother and father is fae... Shetland but they just dinna hae the accent at a'.

Gloss: And with my pals, they were saying about me and Valerie, she's just- me and her are just probably the broadest ones of the lot of us. Cos my other pals, they live in Lerwick and their mother and father are from... Shetland but they just don't have the accent at all.

Thus none of the typical influences on language use - gender, networks, attitudes, exposure to other varieties - can explain the split in the younger speakers ${ }^{6}$. These non-correlations serve to highlight the 'complex array of factors which come into play, ranging from a variety of situational contexts to the proactive personal initiative of speakers in the construction of a linguistic self" (Wolfram 2002:766) in the face of rapid language attrition. Uncovering this complex array of factors may require more in-depth ethnographic study of the community in future research (e.g Mendoza-Denton 1997). Whatever the reasons for the split in this younger age group, the results across the individuals demonstrate a highly unusual pattern in terms of language change. Hill (1989) suggests that the only difference between language change and language death is the speed at which it proceeds. These results suggest otherwise, with a severe break in community norms with half of the younger speakers in the space of one generation. Wolfram (2008:1) poses the question 'what sociolinguistic responses might be adopted by islanders who suffer the loss of an emblematic language variety?' In this case, the answer is 'very different responses'. 
While the reasons for the patterns of use across the individual speakers cannot currently be fully explained, can the linguistic details of change tell us anything about the processes involved in dialect attrition? As discussed above, the younger speakers conform to two broad patterns: variable use of dialect features vs. near categorical use of Standard (Scottish) English features. Beyond this broad categorisation, what can analysis of the linguistic details of use reveal? Dorian (e.g. 1994) suggests that in the process of rapid language attrition, a system of 'personal pattern variation' (Dorian 1994) develops: severe intraspeaker variability with little or no correlation with social or linguistic factors, or to other members of the community. Christian, Wolfram and Dube (1988:79) find that 'orderly progression of change and variation is not quite so neat as some variationists... would have us believe, particularly at the endpoints of the change'. Wolfram \& Schilling-Estes (1995:711) also find that variables at the end point of change will exhibit upheaval in the 'natural ordering of constraint effects'. In contrast, linguistic features on the verge of extinction may continue to retain systematic linguistic conditioning (Jones \& Tagliamonte 2004). The rapidity of change with one group in the younger speakers makes it difficult to analyse potential endpoints of a change: they have simply adopted the standard forms more or less wholesale. Further analysis of the variable younger speakers in these data, however, reveal shared linguistic constraints across a number of variables, arising from transmission and maintenance of linguistic constraints from previous generations. There is no chaotic retreat of the system, but instead orderly differentiation and maintenance of constraints of the type found in language change more generally.

A second important finding is that while constraints were similar, the analysis revealed heightened rates of use in the younger speakers with some variables, most strikingly demonstrated by the use of $y o n^{7}$. The question is why? Britain (2009:133) 
points out that 'some dialects under the potential threat of attrition, particularly isolated rural ones... appear to resist erosion and occasionally change in ways diverge from the incoming innovation'. This was first demonstrated in Labov's seminal 1963 study of Martha's Vineyard and more recently in the moribund dialect of Smith Island (e.g. Schilling-Estes 1997, 2000; Schilling-Estes and Wolfram 1999), where the dialect spoken is becoming more, rather than less, divergent with certain variables. Wolfram \& Schilling-Estes describe these patterns as a concentration model in which 'structural distinctiveness is intensified among a reduced number of speakers' (Wolfram 2002:769). Some forms take on 'socio-symbolic meaning' (Schilling-Estes and Wolfram 1994, Schilling-Estes 2000), resulting from an increasing sense of solidarity amongst the islanders in the face of potential attrition. A concentration model may be signalled by both higher rates of use of particular features, and also different patterns of use in some cases, demonstrated, for example, by the remorphologisation of was and were (Schilling-Estes \& Wolfram 1994). In the Shetland data, although the rates were higher with some younger speakers, the structured heterogeneity evidenced in the older age groups remained intact. In other words, these speakers are not using the forms hyperdialectally (e.g. Trudgill 1986:75) - the extension of the local form to 'linguistic contexts where it was not previously used' (Britain 2009: 135) - but simply using the local forms at higher rates. This may be a form of statistical rather than structural hyperdialectalism (e.g. Wolfram \& Schilling-Estes 2006) on the part of the younger dialectal speakers in their resistance strategies. However, in many cases 'these resistance strategies can sometimes be relatively short-lived... often appearing as a last gasp before final attrition' (Britain 2009:133-4) 
The one variable which stands out from the cohort in terms of patterning of use is th- stopping. First, none of the speakers showed remarkably high rates of use: even the speakers with the highest rates used the stop variants at rates similar to, or lower than, the older speakers. In other words, no evidence of statistical hyperdialectalism. Second, its use is best characterised as gradient stratification amongst the younger cohort, with intra- rather than inter-speaker variation. Third, and perhaps most important, the non-standard variant used differed according to generation: in the majority of cases, the older speakers used a dental stop, while the younger speakers used an alveolar stop (see Smith, Durham and Holmes, in progress for a detailed analysis of this variable). This variant might be interpreted as intensification of dialect variants as in the concentration model, or structural hyperdialectalism. This would be unexpected however, given that all the younger speakers participate in this use, even those who are very standard with all other variables analysed. Instead, the explanation may again lie in moribund dialect features. Melchers (2004b:45) points out that 'the articulatory setting in Shetland speech is generally fronted', and the Scandinavian substratum is the suggested source $^{8}$. In this case, the dental variant may be the result of substratum influence and its decline across the generations may signal a decline in influence of the substratum. The use of the alveolar stop in the younger speakers is not interpreted as intensification of dialect forms but simply that the younger speakers are turning to an already available phoneme in their phonological inventory as the influence of Scandinavian features wane.

Taken together, these results provide support for Trudgill's (2002:41) observation that 'In the process of dedialectalism...dialect variants disappear at different speeds'. The type of linguistic variable may be implicated in this, with our 
results pointing to a distinction between dialect and accent features (e.g. Petyt 1980). It also demonstrates that some variables such as yon may be subject to 'sociolinguistic focussing' (Wolfram 2002:780), signaled by their extremely high rates of use. In other words, they become symbolic, and hence used as 'acts of identity' (Le Page \& Tabouret-Keller 1985) in the portrayal of 'Shetlandness' or indeed 'Scottishness' in the face of potential external threat. Others may not have such symbolism and simply quietly slip away through time?

\section{CONCLUSION}

This study provides the first quantitative analysis of language change in Lerwick, Shetland and highlights the complexities of obsolescence where decline in use of forms 'cannot be reduced neatly to a universally predictable regression slope' (Wolfram's (2002:766). The results show dramatic dialect shift in the space of three generations which leads us to suggest that the dialect may be facing rapid dialect attrition. However, as Hoenigswald (1989: 353) suggests, 'demise can be predicted, it seems, only at a terminal stage', where there are, for example, only a few remaining speakers of the dialect in question. Therefore, to paraphrase Mark Twain, reports of dialect death may be greatly exaggerated. The only way we can be sure our interpretation is 'right' is to return to Lerwick in 30 years time to see if we can still hear peerie, I'm no been there and /d/at wife /d/ere. 
${ }^{1}$ Acknowledgements

We gratefully acknowledge the support of the Economic and Social Research Council for award number 000-22-2052. We would like to thank three anonymous reviewers for their extremely helpful comments. We would also like to thank Sophie Holmes and Andrew McFarlane for help in coding of data. Thanks are also due to our three invaluable on-site fieldworkers, Mary Blance, Laureen Johnson and Douglas Sinclair, and Doreen Waugh for help with dialect transcription issues. We dedicate this article to the speakers of Lerwick, Shetland.

${ }^{2}$ One reviewer notes that 'in a minor sort of way Lerwick speech is an urban variety'.

${ }^{3}$ Although one reviewer comments that this may be a rather exaggerated view of this lexical item.

${ }^{4}$ All perfect tense contexts were included. Contexts of contracted ' $s$ as in It's been a good shop to work in were excluded as it is impossible to establish whether ' $s$ is is or has.

${ }^{5}$ In casual speech, /ð/ is frequently modified from its full form. In addition to stoplike realisations, it may also become nasalized, lateralized, or omitted all together. For the purposes of this study, we concentrate only on those cases where the contexts were realised as a dental fricative or a stop. All other variants were excluded.

${ }^{6}$ Schooling is traditionally cited as a cause of dialect loss. As pointed out by many of the older generations, they would have been 'flitten on badly' for speaking dialect in class. However, for the younger generation, there have been a number of dialect awareness programmes, particularly in primary schools in Shetland and a policy directed change in attitude towards use of the vernacular in the school setting. Hence it would be unlikely that the change in dialect use is due to schooling practices.

7 This might be interpreted as 'dialect performance' (e.g. Coupland 2001, SchillingEstes 1998), an 'exaggerated' version of their vernacular speech produced for the microphone. However, instead of demonstrating the switches normally associated with such 'hyper-performance' in the sociolinguistic interview (e.g. Schilling-Estes 1998) the speakers who used the forms at high rates did so throughout the hour long recording.

${ }^{8}$ We thank an anonymous reviewer for drawing attention to this research.

${ }^{9}$ The results from this research may lend themselves to an entirely different - and apparently more upbeat - interpretation. Instead of dialect attrition, the younger speakers are bidialectal (e.g. Cornips and Hulk, 2006:355) as Melchers (2004: 37) has already suggested. We are currently exploring this possibility in further research (Smith 2007-9) 


\section{REFERENCES}

Bailey, Guy. 2002. Real and apparent time. In J.K. Chambers, Peter Trudgill, and Natalie Schilling-Estes (eds.) The Handbook of Language Variation and Change. Oxford, England: Blackwell. 312-331.

Barnes, Michael. 1998. The Norn Language of Orkney and Shetland, Lerwick: The Shetland Times Ltd.

Britain, David. 2005. The dying dialects of England? In Antonio Bertacca (ed.) Historical linguistic studies of spoken English. Pisa: Edizioni Plus. 35-46.

Britain, David. 2009. One foot in the grave?: Dialect death, dialect contact and dialect birth in England. In David Britain, Reinhild Vandekerckhove and Willy Jongenburger (eds.). Dialect Death in Europe? Special Issue of International Journal of the Sociology of Language 196/197:121-159.

Bugge, Edit. 2007. Shetlan Wirds. En studie av kjennskap til og oppfatninger om det shetlandske dialektordforrådet. Masteroppgave ved Nordisk Institutt, Universitetet i Bergen.

Campbell, Lyle and Martha Muntzel. 1989. The structural consequences of language death. In Nancy C. Dorian (ed.), Investigating Obsolescence. Cambridge: Cambridge University Press. 181-96.

Catford, John C. 1957. 'The linguistics survey of Scotland', Orbis 6: 105-21.

Chambers, J. K. 2002. 'Patterns of Variation including change. In J. K. Chambers, Peter Trudgill, and Natalie Schilling-Estes, (ed.), The Handbook of Language Variation and Change Oxford: Blackwell. 349-372 
Christian, Donna, Walf Wolfram and Nanjo Dube. 1988. Variation and change in geographically isolated communities: Appalachian English and Ozark English. Tuscaloosa: University of Alabama Press.

Cornips, Leonie and Aafke Hulk. 2006. External and internal factors in bilingual and bidialectal language development: grammatical gender of the Dutch definite determiner. In Claire Lefebvre, Lydia White and Christine Jourdan (eds.). L2 acquisition and creole genesis: dialogues. Amsterdam: John Benjamins. 35578.

Coupland, Nikolas. 2001. Dialect stylization in radio talk. Language in Society 30: $345-375$.

Dannenberg, Clare 2003. Sociolinguistic Constructs of Identity: The Syntactic Delineation of a Native American English Variety. (Publication of the American Dialect Society No. 87.) Durham: Duke University Press.

Dons, Ute. 2004. Descriptive Adequacy of Early Modern English Grammars. Berlin: Mouton de Gruyter.

Dorian, Nancy C. 1977. The problem of the semi-speaker in language death. International Journal of the Sociology of Language 12: 23-32.

Dorian, Nancy C. 1981. Language death: The life cycle of a Scottish Gaelic dialect. Philadelphia: University of Pennsylvania Press.

Dorian, Nancy C. 1986. Abrupt transmission failure in obsolescing languages: How sudden the "tip" to the dominant language communities and families. In V. Nikiforidu, M. Van Clay, M. Niepokuj and D. Feder (eds.), Proceedings of the Twelfth Annual Meeting of the Berkeley Linguistics Society. Berkeley: Berkeley Linguistics Society. 72-83. 
Dorian, Nancy C. (ed.) 1989. Investigating Obsolescence: Studies in Language

Contraction and Obsolescence. Cambridge: Cambridge University Press.

Dorian, Nancy C. 1994. Varieties of variation in a very small place: Social homogeneity, prestige norms, and linguistic variation. Language 70: 631- 96.

Feagin, Crawford. 1979. Variation and Change in Alabama English: A Sociolinguistic Study of the White Community. Washington, D.C.: Georgetown Univ. Press.

Foulkes, Paul and Gerry Docherty (eds.). 1999. Urban Voices: Accent Studies in the British Isles. England: Arnold.

Guy, Gregory R. 1980. Variation in the group and the individual: The case of final stop deletion. In William Labov (ed.), Locating language in time and space. New York: Academic Press. 1-36.

Hill, Jane H. 1989. The social functions of relativization in obsolescent and nonobsolescent languages. In Nancy C. Dorian (ed.), Investigating Obsolescence. Cambridge: Cambridge University Press. 149-166.

Hinskens, Frans, Peter Auer and Paul Kerswill. 2005. The study of dialect convergence and divergence: conceptual and methodological considerations. In Peter Auer and Frans Hinskens and Paul Kerswill (eds.) Dialect change. The convergence and divergence of dialects in contemporary societies. Cambridge: Cambridge University Press. 1-48.

Hoenigswald, Henry M. 1989. Language obsolescence and language history: matters of linearity, levelling, loss, and the like. In Nancy C. Dorian (ed.), Investigating Obsolescence, Cambridge: Cambridge University Press. 347-54.

Jakobsen, Jakob. 1921/1928. Etymologisk Ordbog over det Norrøne Sprog på Shetland. Translated as An Etymological Dictionary of the Norn Language in Shetland, 2 volumes, London: David Nutt. 
Johnson, Wyn and David Britain. 2007. L-vocalisation as a Natural Phenomenon: Explorations in sociophonology. Language and Sciences 29: 294-315.

Johnston, Paul. 1997. Regional variation. In Charles Jones (ed.) The Edinburgh History of the Scots Language. Edinburgh: Edinburgh University Press. 433513.

Jonas, Diane. 1996. Clause Structure and Verb Syntax in Scandinavian and English, unpublished $\mathrm{PhD}$ dissertation, Harvard University.

Jones, Megan \& Tagliamonte, Sali A. (2004). From Somerset to Samaná: pre-verbal did in the voyage of English. Language Variation and Change 16(2): 93-126.

Kerswill, Paul. 2003. Dialect levelling and geographical diffusion in British English. In David Britain and Jenny Cheshire (eds.). Social dialectology. In honour of Peter Trudgill. Amsterdam: Benjamins. 223-243.

King, Anne. 1997. The morphology of Older Scots. In Charles Jones (ed.) The Edinburgh History of the Scots Language. Edinburgh: Edinburgh University Press. 156-181.

King, Ruth. 1989. On the social meaning of linguistic variability in language death situations: Variation in Newfoundland French. In Nancy C. Dorian (ed.), Investigating Obsolescence. Cambridge: Cambridge University Press. 139-48.

Kytö, Merja. 1997. Be/have + past participle: The choice of the auxiliary with intransitives from Late Middle to Modern English. In Matti Rissanen, Merja Kytö and Kirsi Heikkonen (eds.). English in transition: Corpus-based studies in Linguistic Variation and Genre Styles. Berlin: Mouton de Gruyter. 17-84.

Labov, William. 1963. The social motivation of a sound change. Word 19: 273-307 Labov, William. 1972. Sociolinguistic Patterns. Philadelphia: University of Pennsylvania Press. 
Labov, William. 1984. Research methods of the project on linguistic change and variation. In John Baugh and Joel Sherzer, (eds.), Language in use: Readings in sociolinguistics. Englewood Cliffs: Prentice Hall. 28-53.

Labov, William. 1994. Principles of Linguistic Change Internal Factors (Vol. 1). Oxford: Blackwell.

Labov, William. 2001. Principles of linguistic change: Social factors (Vol. 2). Oxford: Blackwell.

Le Page, Robert \& Tabouret-Keller, Andree (1985). Acts of Identity: Creole-based approaches to Language and Identity. Cambridge: Cambridge University Press. Llamas, Carmen. 2000. "Middlesbrough English: Convergent and divergent trends in a 'part of Britain with no identity'." Leeds Working Papers in Linguistics 8: $123-148$.

Macafee, Caroline. 1983. Varieties of English Around the World: Glasgow, Amsterdam: Benjamins.

McMahon, April. 1994. Understanding Language Change. Cambridge: Cambridge University Press.

Melchers, Gunnel. 1985. 'Knappin', 'Proper English', 'Modified Scottish' - Some Language Attitudes in the Shetland Isles, in Manfred Görlach (ed.). Focus On: Scotland. Amsterdam: Benjamins, 87-100.

Melchers, Gunnel. 1991. Norn-Scots: a complicated language contact situation in Shetland. In P. Sture Ureland and George Broderick (eds.). Language Contact in the British Isles: Proceedings of the Eighth International Symposium on Language Contact in Europe, Douglas, Isle of Man, 1988. Linguistische Arbeiten 238. Tübingen: Max Niemeyer, 461-477. 
Melchers, Gunnel. 1992 “Du's no heard da last o' dis”- on the use of be as a perfective auxiliary in Shetland dialect. In Matti Riisanen (ed.) History of Englishes: New Methods and Interpretations in Historical Linguistics. Berlin: Mouton de Gruyter, 602-610.

Melchers, Gunnel. 1996. "We're aa da same here - but different, too": some notes on regional linguistic variation in Shetland'. In Doreen Waugh, Brendan Smith (eds.). Shetland's northern links: language and history. Edinburgh: Scottish Society for Northern Studies. 44-51.

Melchers, Gunnel. 1997. This, that, yon: on 'three-dimensional' deictic systems. In Cheshire, Jenny and Dieter Stein (eds.), Taming the Vernacular. London: Longman. 83-92.

Melchers, Gunnel. 2004a. English spoken in Orkney and Shetland: Morphology, syntax and lexicon. In Bernd Kortmann and Edgar.Schneider (eds.). A Handbook of Varieties of English, Vol. 2 Morphology and Syntax. Berlin: Mouton de Gruyter. 34-47.

Melchers, Gunnel. 2004b. English spoken in Orkney and Shetland: Morphology, syntax and lexicon. In Bernd Kortmann and Edgar.Schneider (eds.). A Handbook of Varieties of English, Vol. 1 Phonology. Berlin: Mouton de Gruyter. 35-47.

Millar, Robert. 2007. Northern and Insular Scots. Edinburgh: Edinburgh University Press.

Miller, James. 1993. The grammar of Scottish English. In James Milroy and Lesley Milroy (eds.). Real English: The Grammar of English Dialects in the British Isles, Harlow: Longman. 99-138.

Milroy, Lesley. 1980. Language and social networks. London: Basil Blackwell. 
Murison, David. 1954. Scots speech in Shetland. In William Douglas Simpson (ed.). The Viking Congress, Lerwick, July 1950, Edinburgh: Aberdeen University Studies 132:255-260.

Oxford English Dictionary. Accessed September 22, 2009 at: www.oed.com/ Pavlenko, Alexander. 1997. The origin of the be-perfect with transitives in the Shetland dialect. Scottish Language 16: 88-96.

Petyt, Keith M. 1980. The Study of Dialect. London: Andre Deutsch Limited Rendboe, Laurits. 1984. How "worn out" or "corrupted" was Shetland Norn in its final stage? NOWELE 3: 53-88.

Robertson, T. A. and John Graham. 1952/1991. Grammar and Usage of the Shetland Dialect, Lerwick: Shetland Times Ltd.

Schilling-Estes, Natalie. 1997. Accommodation versus Concentration: Dialect Death in Two Post-Insular Island Communities. American Speech 72:12-31.

Schilling-Estes, Natalie. 1998. Investigating ‘self-conscious’ speech: The performance register in Ocracoke English. Languge in Society 27: 53-83

Schilling-Estes, Natalie and Walt Wolfram (1994). Convergent explanation and alternative regularization: Were/weren't leveling in a vernacular English variety. Language Variation and Change 6: 273-302.

Schilling-Estes, Natalie, and Walt Wolfram. 1999. Alternative models for dialect death: Dissipation vs. concentration. Language 75.3: 486-521.

Sankoff, David., \& Pierre Thibault. 1981. Weak complementarity: tense and aspect in Montreal French. In B.B. Johns \& D.R. Strong (eds.), Syntactic Change. Natural Language Studies 25:205-216.

Scobbie, James. 2005. Interspeaker variation among Shetland Islanders as the long term outcome of dialectally varied input: speech production evidence for fine- 
grained linguistic plasticity. QMUC Speech Science Research Centre Working Papers WP-2.

Scottish National Dictionary. Accessed September 22, 2009 at: $\underline{\text { http://www.dsl.ac.uk/index.html }}$

Scotland Census 2001. Accessed online September 212009 at: http://www.scrol.gov.uk/scrol/browser/profile.jsp?profile=Population\&mainAre $\underline{\mathrm{a}=\text { Shetland+Islands\&mainLevel=CouncilArea }}$

Smith, Brian. 1996. The development of the spoken and written Shetland dialect: a historian's view. In Doreen Waugh and Brendan Smith (eds.) Shetland's Northern Links: Language and History, Edinburgh: Scottish Society for Northern Studies. 30-43.

Smith, Jennifer. 2000. Synchrony and diachrony in the evolution of English: Evidence from Scotland. Unpublished PhD thesis, University of York, York, England.

Smith, Jennifer. 2001. Ye $\varnothing$ na hear that kind o’ things: Negative do in Buckie. English World Wide 21(2): 231-259.

Smith, Jennifer. 2007-9. Bidialectalism or dialect death? Young speakers and language change in Lerwick, Shetland. British Academy Research Grant.

Smith, Jennifer and Mercedes Durham (in progress). I'm no been there in a while: the be perfect in Lerwick Shetland.

Smith, Jennifer, Mercedes Durham and Sophie Holmes. (in progress). Dis 'n' dat: constraint change across the generations in Lerwick, Shetland.

Stuart-Smith, Jane, Claire Timmins and Fiona Tweedie. 2007. Talking Jockney: Variation and change in Glaswegian accent. Journal of Sociolinguistics 11(2): $221-260$. 
Sundkvist, Peter. 2007. The pronunciation of Scottish Standard English in Lerwick, Shetland. English World-Wide 28 (1):1-21.

Tagliamonte, Sali. 1997. Obsolescence in the English perfect? Evidence from Samaná English. American Speech 72(1):33-68.

Tagliamonte, Sali. 2000. The grammaticalization of the present perfect in English: Tracks of change and continuity in a linguistic enclave. In Olga Fischer, Anette Rosenbach, and Dieter Stein (eds.). Pathways of Change: Grammaticalization in English. Amsterdam: John Benjamins. 329-354.

Tait, John. 2001. "Whit is Shetlandic?", Lallans 58. 7-16.

Trudgill, Peter. 1986. Dialects in Contact. Oxford: Blackwell.

Trudgill, Peter. 2002. Sociolinguistic Variation and Change. Edinburgh: Edinburgh University Press.

Tsitsipis, Lukas. D. 1989 'Skewed performance and full performance in language obsolescence: The case of an Albanian dialect', in Nancy C. Dorian (ed) Investigating Obsolescence: Studies in Language Contraction and Death, Cambridge: Cambridge University Press. 139-148.

van Leyden, Klaske. 2004. Prosodic Characteristics of Orkney and Shetland Dialects. An Experimental Approach. PhD Dissertation, Leiden University (LOT Dissertation Series 92). Utrecht: LOT.

Wells, John, C. 1982. Accents of English. Cambridge: Cambridge University Press.

Wolfram, Walt. 1996. Delineation and description in dialectology: The case of perfective I'm in Lumbee English. American Speech 70:5-26.

Wolfram, Walt. 2002. 'Language death and dying'. In J. K.Chambers, Peter Trudgill, and Natalie Schilling-Estes (eds.). The Handbook of Language Variation and Change Oxford: Blackwell. 764-787. 
Wolfram, Walt. 2008. When islands lose dialects: The Case of the Ocracoke Brogue. In Shima: The International Journal of Research into Island Cultures 2(1):1-13

Wolfram, Walt and Natalie Schilling-Estes. 2006. American English: dialects and variation. $2^{\text {nd }}$ Edition. Oxford: Blackwell. 


\section{FIGURES}

Figure 1: Scotland, the Shetland Isles and Lerwick

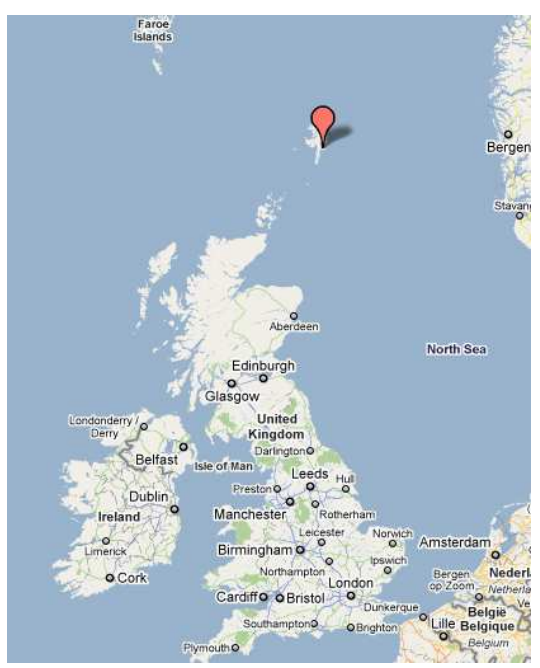

For review only. Confidential. Should not be cited. 
Figure 2: Lerwick, Shetland

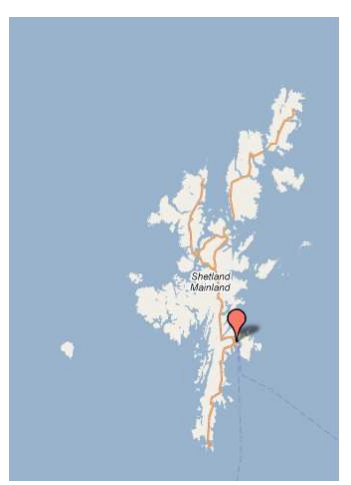


Figure 3: Percentage of local lexical forms by speaker age

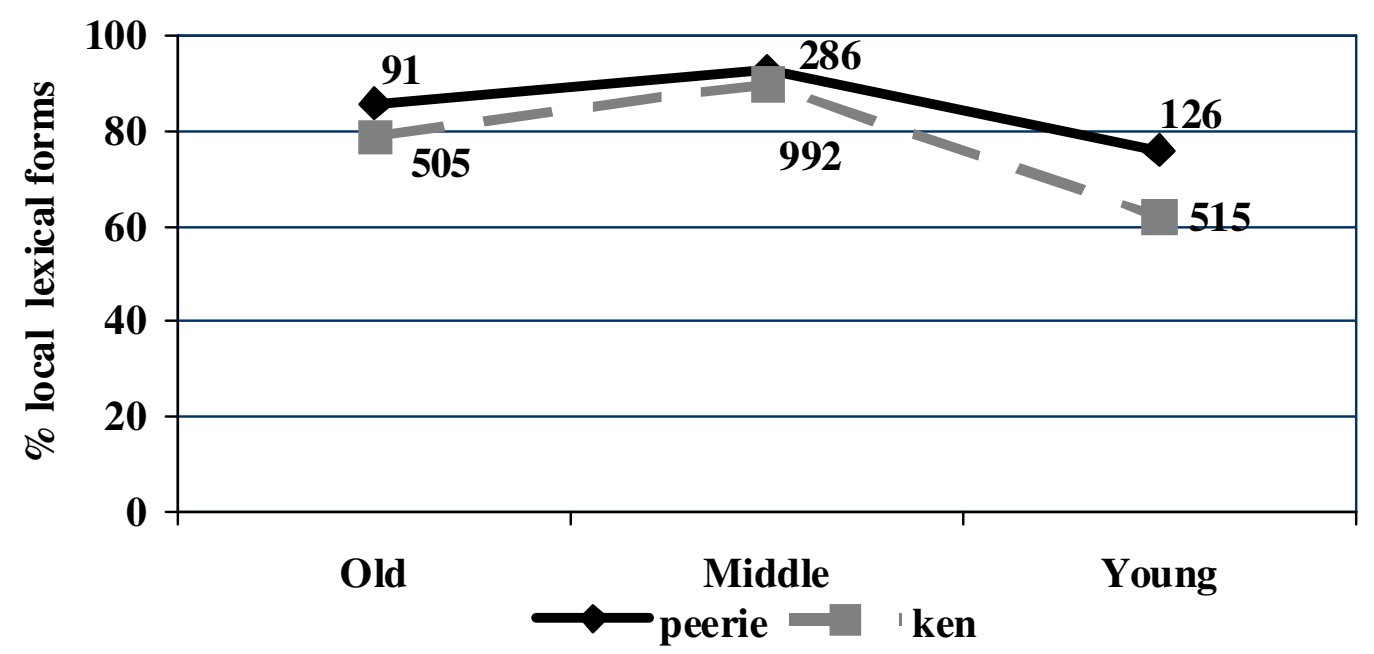

For review only. Confidential. Should not be cited. 
Figure 4: Percentage of local lexical forms by individual young speaker

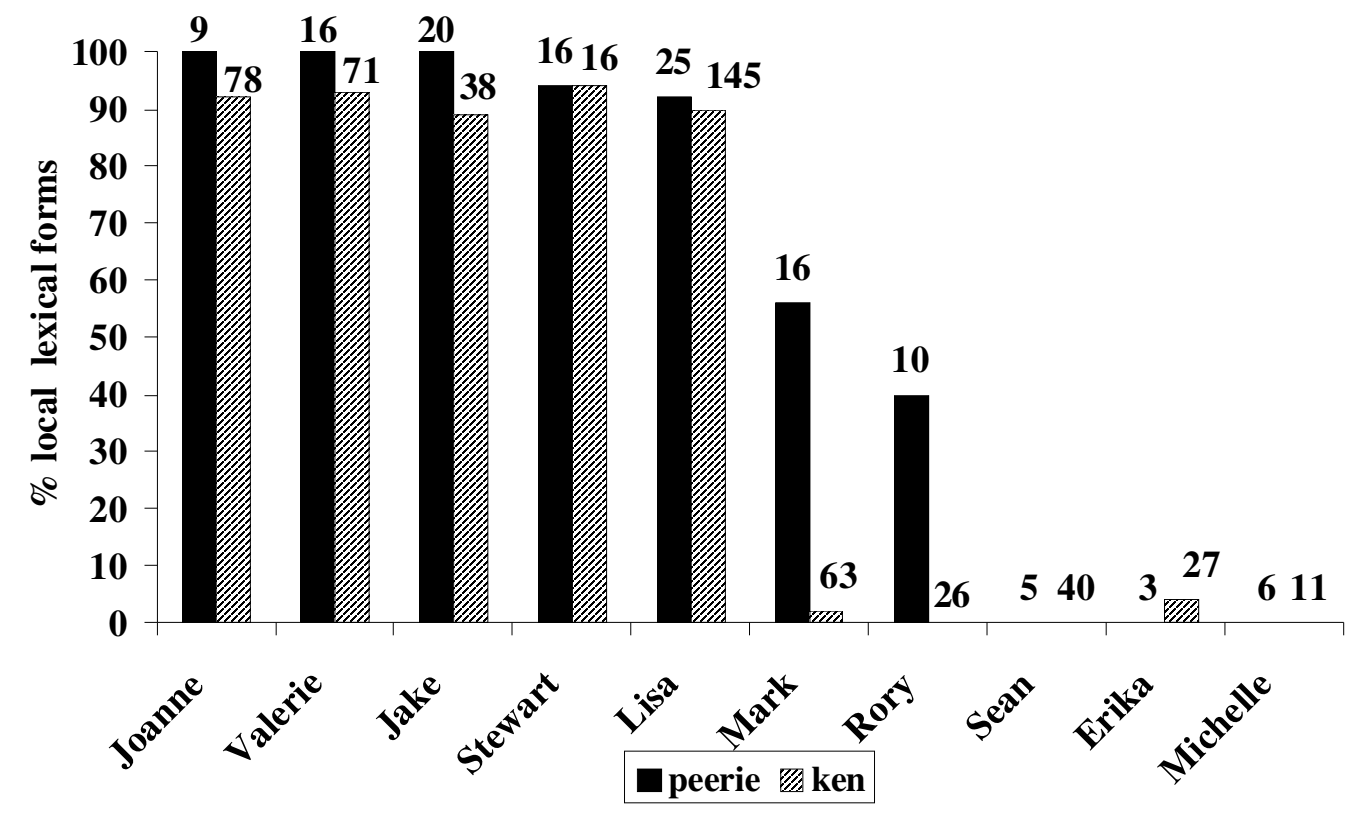


Figure 5: Percentage of local morphological forms by speaker age

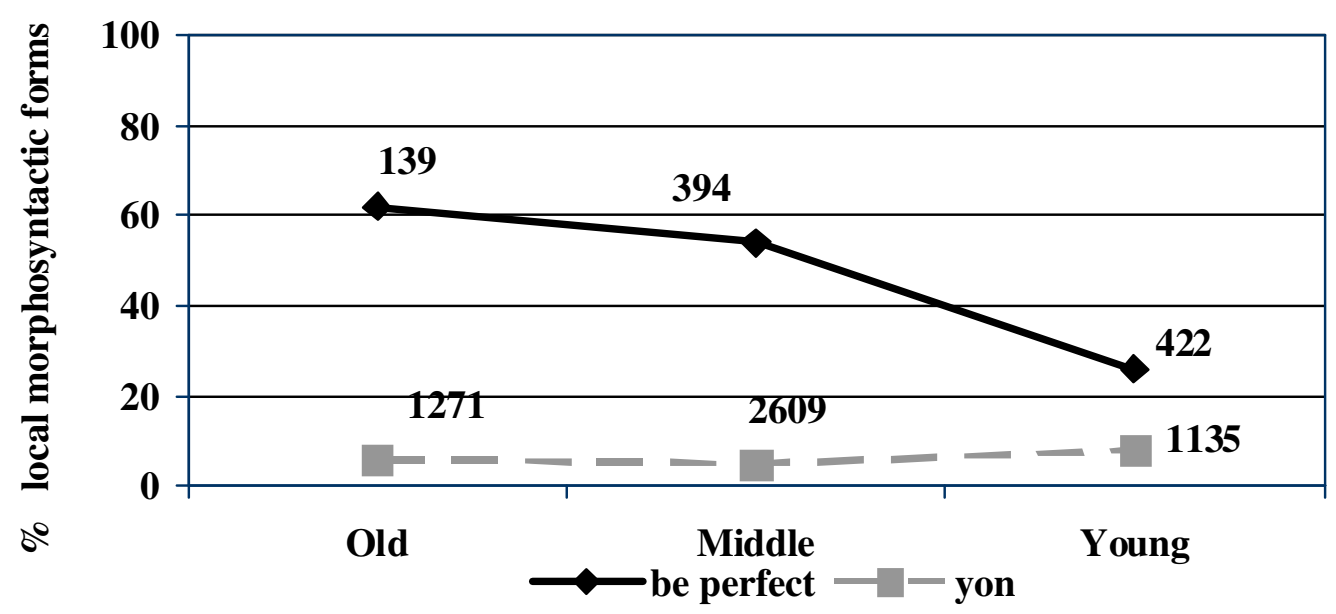


Figure 6: Percentage of local morphological forms by individual young speaker

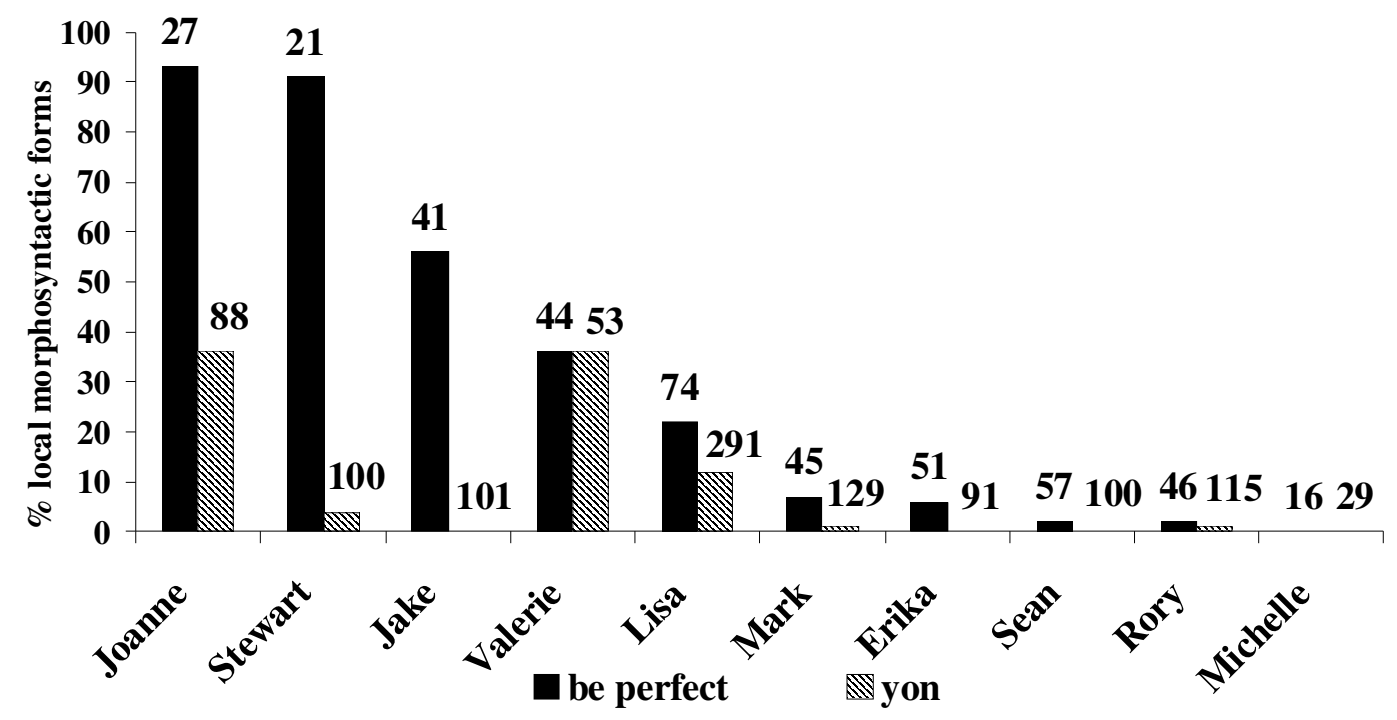


Figure 7: Percentage of be for have by tense and age

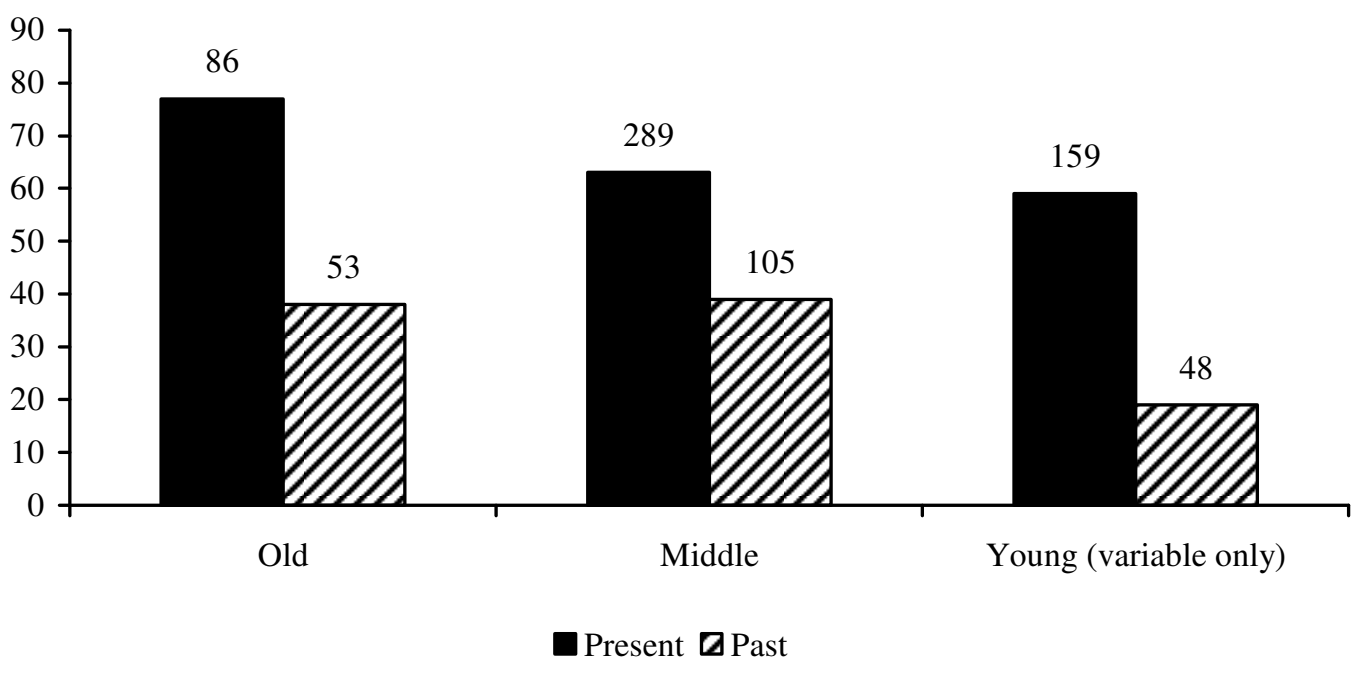

27

28

29

30

31

32

33

36

37

38

39

40

41

42

43

44

45

46

47

48

49

50

51

52

53

54

55

56

57

58

59

60

For review only. Confidential. Should not be cited. 
Figure 8: Percentage of yon by type and age

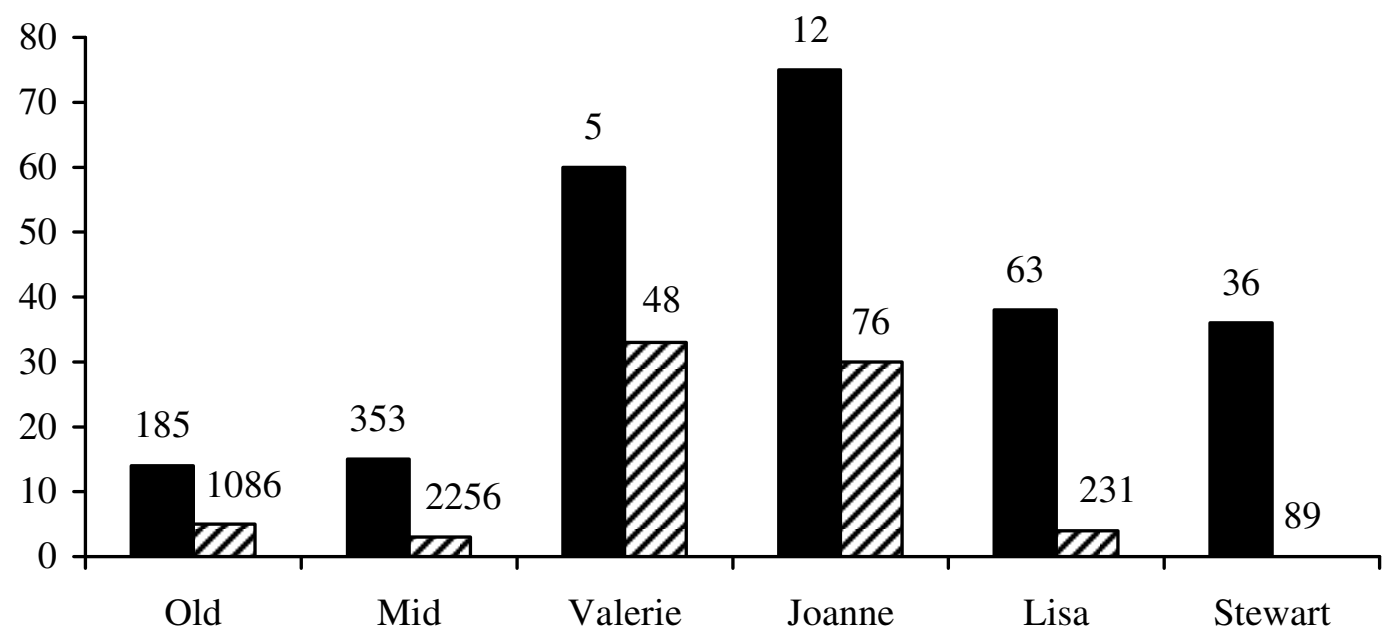

Determiner $\boldsymbol{\nabla}$ Pronoun

For review only. Confidential. Should not be cited. 
Figure 9: Percentage of local phonological forms by speaker age

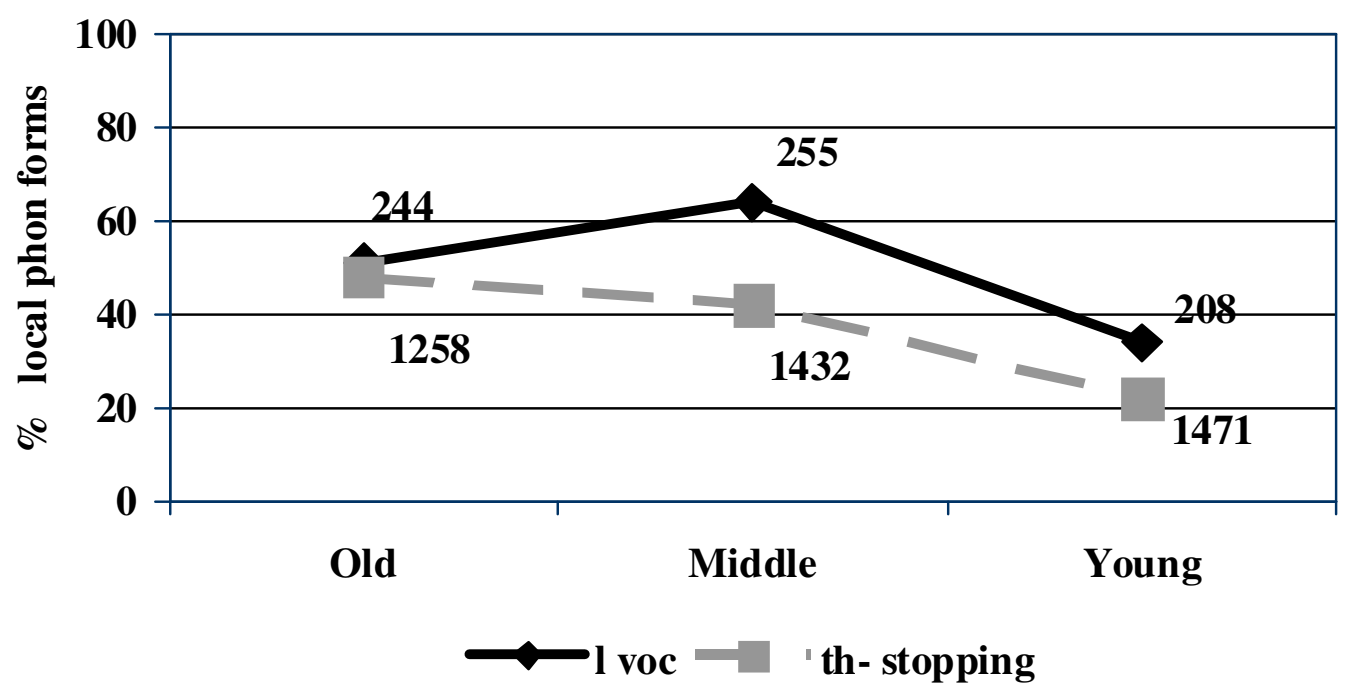


Figure 10: Percentage of local phonological forms by individual young speaker

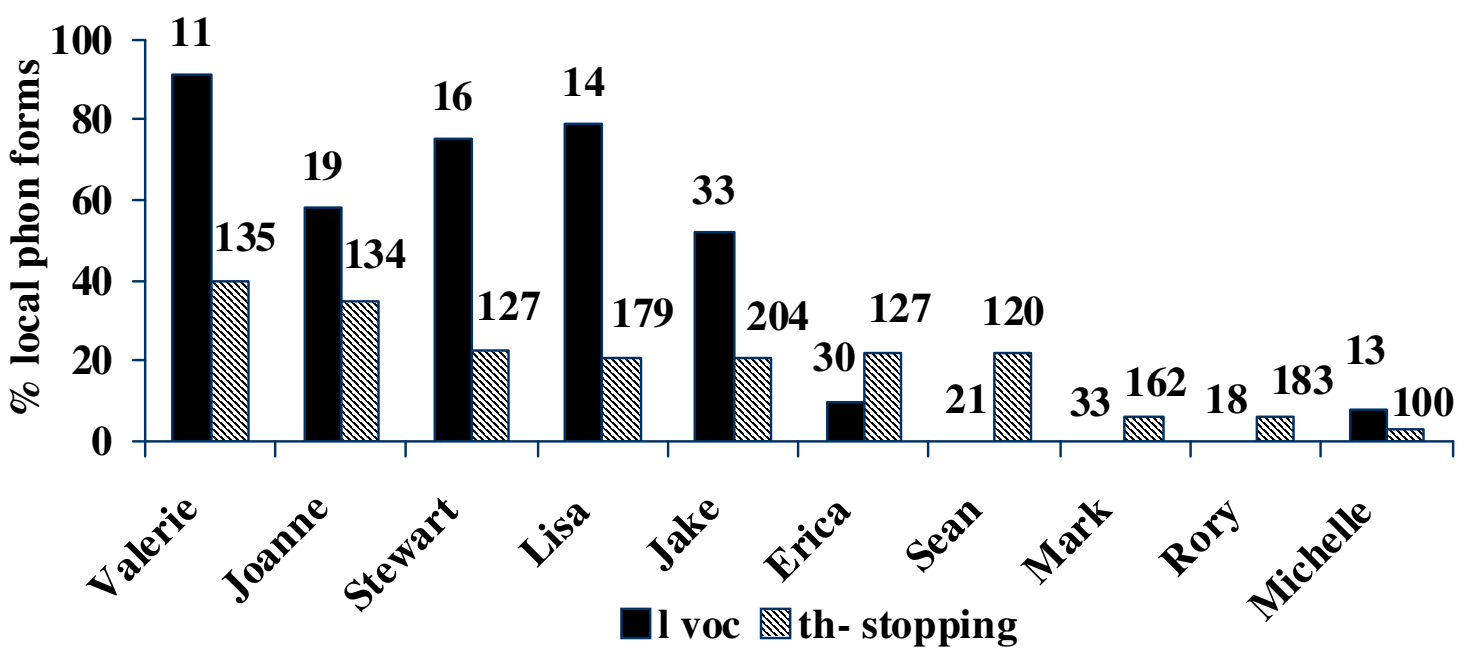


Figure 11: voiced $<$ th $>$ pronunciation by age

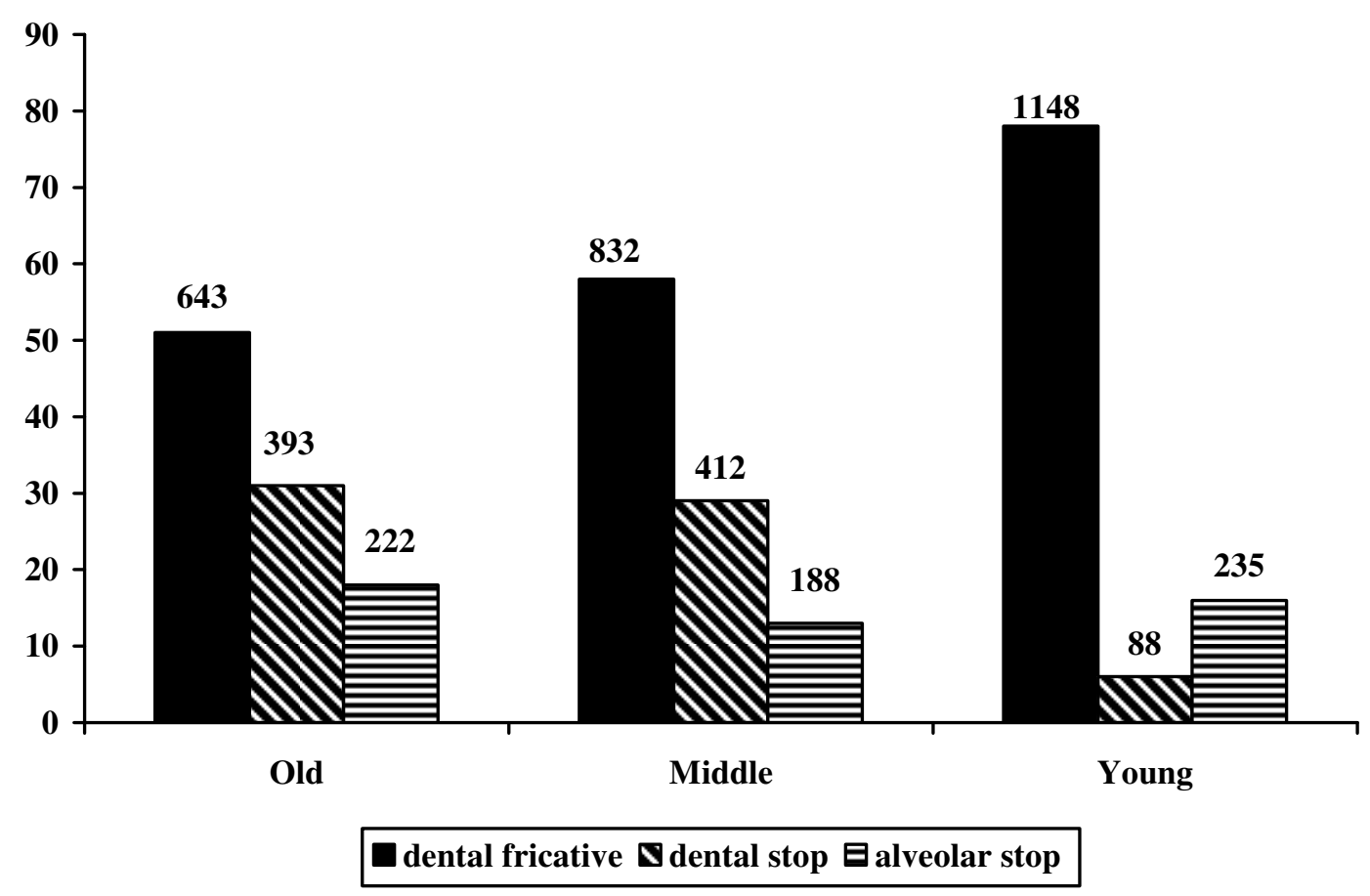

For review only. Confidential. Should not be cited. 